\title{
Ultrastructural and molecular characterization of Tetraselmis strains (Chlorodendrophyceae, Chlorophyta) isolated from Chile
}

\section{Caracterización ultraestructural y molecular de cepas de Tetraselmis (Chlorodendrophyceae, Chlorophyta) aisladas de Chile}

\author{
Mariela A. González ${ }^{*}$, Paula A. Aguayo1, Ingrid de L. Inostroza ${ }^{1}$, Pablo A. Castro¹, Glenda A. \\ Fuentes ${ }^{2}$ \& Patricia I. Gómez ${ }^{1}$
}

${ }^{1}$ FICOLAB (Grupo de Investigación Microalgal) y ²Laboratorio de Sistemática Molecular, Departamento de Botánica, Facultad de Ciencias Naturales y Oceanográficas, Universidad de Concepción, casilla 160-C, Concepción, Chile. *mgonzale@udec.cl

\begin{abstract}
Species of the genus Tetraselmis (Chlorodendrophyceae, Chlorophyta) have traditionally been used in aquaculture facilities as food for larval varieties of marine organisms. Recently, some strains with high lipid content have been considered as having potential for biofuel production. Although many Tetraselmis species are relatively well-characterized using light and electron microscopical methods, there are still taxonomic ambiguities among the species. DNA sequence analysis, which provides a reliable and more convenient tool for species delimitation, has been poorly used in Tetraselmis. In this study, three strains of Tetraselmis, isolated from coastal Chilean waters, have been characterized using an integrative approach (light and electron microscopy, molecular phylogeny of ITS, including secondary structure analysis). According to the pyrenoid ultrastructure of the strains investigated two of them (from Dichato and Coliumo) belong to the subgenus Parviselmis, while the Caldera strain corresponds to the subgenus Tetrathele. Even though it was not possible to identify the strains at species level, it was clearly demonstrated by phylogenetic analyses of ITS- 1 and ITS- 2 sequences and by ITS-2 secondary structure that the Dichato and Coliumo strains are the same species, and could belong either to T. suecica or T. chui. However, the Caldera strain might correspond to an undescribed species. As our study has shown, the genus Tetraselmis needs to be taxonomically revised using an integrative approach, which includes the investigations of authentic strains of this genus.
\end{abstract}

KEYWORDS: Cell ultrastructure, ITS region sequences, ITS-2 secondary structure, Tetraselmis strains.

\section{RESUMEN}

Especies del género Tetraselmis (Chlorodendrophyceae, Chlorophyta) han sido tradicionalmente usadas en centros acuícolas como alimento para larvas de una variedad de organismos marinos. Adicionalmente, algunas cepas con alto contenido de lípidos han sido recientemente consideradas como fuente potencial para la producción de biodiesel. Aunque muchas especies de Tetraselmis se encuentran morfológica y ultraestructuralmente bien caracterizadas, todavía hay ambigüedades taxonómicas al interior del género. El análisis de secuencias de ADN, una herramienta complementaria y conveniente para delimitar especies, ha sido pobremente utilizado en Tetraselmis. En este estudio, se caracterizaron tres cepas de Tetraselmis, aisladas de aguas costeras chilenas, utilizando un enfoque integrativo (morfología, ultraestructura y filogenia molecular). Basado en la ultraestructura del pirenoide de las cepas estudiadas, dos de ellas (Dichato y Coliumo) pertenecen al subgénero Parviselmis, mientras que la cepa de Caldera corresponde al subgénero Tetrathele. Aunque no fue posible identificar las cepas a nivel específico, el análisis filogenético de las secuencias ITS-1 e ITS-2 y la estructura secundaria del ITS-2 demostraron claramente que las cepas de Dichato y Coliumo son la misma especie, y podrían pertenecer a $T$. suecica o a T. chui, mientras que la cepa de Caldera podría corresponder a una especie no descrita aún para la ciencia. Los resultados obtenidos demuestran la necesidad de llevar a cabo una revisión taxonómica del género Tetraselmis, utilizando un enfoque integrativo, el cual incluya las cepas auténticas de las especies.

Palabras clave: Cepas de Tetraselmis, estructura secundaria del ITS-2, secuencias de la región ITS, ultraestructura celular.

\section{INTRODUCTION}

The genus Tetraselmis Stein (Chlorodendrophyceae, Chlorophyta) groups quadriflagellates unicellular organisms, widely recognized in aquaculture since they serve as food for a variety of marine organisms (DSouza \& Kelly 2000, Brown 2002, Meseck et al. 2005, De la Pena \& Villegas 2005). More recently, high lipid-containing strains of this genus have been proposed for biofuel production (Montero et al. 2010, Grierson et al. 2012).

In Tetraselmis, the cells are usually compressed and the four flagella are located in opposite pairs. They are thick of equal length, shorter than the length of the cell, covered by hairs and scales, and are inserted into an apical cell depression. The flagellar apparatus of Tetraselmis consists of four zigzag arranged basal bodies associated with microtubular roots 
and two distinct rhizoplasts. Usually, two dictyosomes are restricted to the region surrounding the basal body complex. The cell is surrounded by a close-fitting periplast of fused scales. A single large chloroplast is present in each cell. The chloroplast is anteriorly lobed, and the posterior part may or may not be lobed, with one pyrenoid and with or without an eyespot. Cells reproduce asexually by simple division within the mother cell commonly forming two daughter cells usually in an inverted position from each other. Sexual reproduction is unknown (Graham \& Wilcox 2000).

The genus is divided into four subgenera (Tetraselmis, Prasinocladus, Tetrathele and Parviselmis) containing 25 species (Hori et al. 1982). The identification of the subgenera depends on characteristics that are visible only with an electron microscope (EM), specially the pyrenoid ultrastructure (Hori et al. 1982, 1983, 1986). The described species differ mostly in cell size, cell shape, chloroplast morphology and the presence/ absence and position of the eyespot. Nevertheless, most of these features are not good descriptors, so the taxonomy within the genus is confusing. Ultrastructural features such as flagellar scales and flagellar hairs had been studied by Melkonian (1982), Becker et al. (1990, 1994) and Marin et al. (1993), but no intraspecific variation of flagellar scales has been detected in Tetraselmis. However, Marin et al. (1993) found some intraspecific variation in the flagellar hairs and proposed that this feature may, to some extent, help to clarify the confused taxonomy within the genus when correlated with other ultrastructural and molecular characters.

Recent phylogenetic studies based on SSU rDNA sequences showed that the genus Tetraselmis is monophyletic (Nasare 2002, Lee \& Hur 2009, Arora et al. 2013). However, it is striking that very little is known about molecular studies of Tetraselmis at species level.

In Chile, only one record of Tetraselmis suecica (Kylin) Butcher and Tetraselmis tetrathele (West GS) Butcher exist for the coast of Valparaíso (Catalán 1996), but their identification was based mostly on features observed under light microscopy that, considering the current information, raise some doubt about its taxonomic identity. The aim of this study was to characterize three new Chilean strains of Tetraselmis isolated from Dichato and Coliumo (Bío-Bío Region) and Caldera (Atacama Region) using morphological (light microscopy), ultrastructural (transmission and scanning EM) and molecular markers (ITS region sequences and ITS-2 secondary structure) in order to get a better understanding of the distribution of Tetraselmis in Chile. We used the Internal Transcribed Spacers of the rDNA because it is more variable in sequence than the SSU rDNA gene. In addition, the secondary structure of the ITS-2 for detection of complementary base changes (CBC) has often been taken into account when distinguishing between closely related species (Müller et al. 2007). Studies have shown that one $\mathrm{CBC}$ in a conserved region of the Helix II or III of the ITS-2 is in most cases associated to an inability for sexual reproduction (Coleman 2007, 2009).

\section{MATERIALS AND METHODS}

\section{STRAINS COLLECTION AND ISOLATION}

The strains were collected from water samples using the filtrate of a nylon mesh ( $33 \mu \mathrm{m}$ diameter). The Coliumo and Caldera strains came from waters close to natural populations of the clam digger Ensis macha Molina, located in Coliumo Bay (36 $32^{\prime}$ S; $72^{\circ} 57^{\prime} \mathrm{W}$ ), and of Argopecten purpuratus Lamarck in Caldera Bay $\left(27^{\circ} 05^{\prime} \mathrm{S} ; 70^{\circ} 82^{\prime} \mathrm{W}\right)$. The Dichato strain was collected from a tank located outside the hatchery of the University of Concepción ( $36^{\circ} 33^{\prime} \mathrm{S}$; $72^{\circ} 56^{\prime} \mathrm{W}$ ). Unialgal cultures of the three strains were obtained by either using the Pasteur pipette isolation and washing technique or streaking a drop sample on agar plates (Hoshaw \& Rosowski 1973 ) with $\mathrm{f} / 2$ medium (Andersen 2005). Isolated cells were maintained in Walne medium (Andersen 2005). The strains were cultivated at a photon flux density of $15-20 \mu \mathrm{mol} \mathrm{m}{ }^{-2}$ $\mathrm{s}^{-1}$, a temperature of $15 \pm 2{ }^{\circ} \mathrm{C}$ and a photoperiod 16:8 (L:D) and maintained in the Microalgal Culture Collection at the University of Concepción (CCM-UDEC) (Concepcion, Chile) (see Table I).

STRAINS OBSERVATION UNDER LIGHT AND ELECTRON MICROSCOPY Live cells were examined under an Olympus CX31 microscope fitted with bright field and phase contrast optics. The photomicrographs were taken with an Olympus C3040 camera attached to the microscope.

For Transmission Electron Microscopy (TEM), culture material of the strains was prepared according to the protocol of Moestrup \& Throndsen (1988). Basically, the cells were harvested at $1000 \mathrm{rpm}$ and fixed for one hour in equal volumes of sample with cold $2 \%(\mathrm{v} / \mathrm{v})$ glutaraldehyde in $0.1 \mathrm{M}$ cacodylate buffer at $\mathrm{pH} 7$. To avoid osmotic changes in ultrastructure of the cells, $0.2 \mathrm{M}$ sucrose was added. After three rinses in buffer of decreasing sucrose concentration $(0.2,0.1$ and $0.05 \mathrm{M})$, the cells were treated for $3 \mathrm{~h}$. in cold $2 \%$ osmium acid in $0.1 \mathrm{M}$ cacodylate buffer, followed by a wash in sucrose buffer and dehydrated in ethanol $(30 \%, 50 \%, 70 \%$, and twice in absolute ethanol) for $15 \mathrm{~min}$ each. Dehydration was completed by two 5-min treatments in propylene oxide and kept overnight in a mix of 1:1 propylene oxide and Spurr's resin. Finally, the samples were polymerized in Spurr's resin at $60^{\circ} \mathrm{C}$. Ultrathin sections were obtained using a SORVALL MT 5000 (DU PONT) ultramicrotome, collected on slot grids and double-stained with uranyl acetate and lead citrate (Reynolds 1963). Observations were carried out with a JEOL JEM 1200EX-II transmission electron microscope. The photomicrographs were taken with a camera (Gatan Mod. 782, Gatan Inc. USA) attached to the microscope.

For Scanning Electron Microscopy (SEM), culture material of the strains was prepared following the protocol of Laza-Martínez (2012) with modifications. Ten $\mathrm{ml}$ of the algal suspension was centrifuged for $10 \mathrm{~min}$ at $1000 \mathrm{rpm}$ and the pellet fixed in Lugol's solution overnight. Then the 
TABLE I. List of the strains used in this study (*authentic strain).

TABLA I. Lista de las cepas utilizadas en este estudio (*cepa auténtica).

\begin{tabular}{|c|c|c|c|c|}
\hline Strain Number & SPECIES & ORIGIN & $\begin{array}{l}\text { ACCESSION } \\
\text { NuMBER }\end{array}$ & REFERENCE \\
\hline WDCM NCC62 & T. suecica & France & AY574382 & $\begin{array}{l}\text { Joubert } \\
\text { et al. } 2002 \\
\text { (Unpublished) }\end{array}$ \\
\hline CCAP $8 / 6^{*}$ & T. chui & Scotland, Millport, Clyde estuary, marine & - & Nasare 2002 \\
\hline CCAP $66 / 21 B$ & T. chui & England, Yorkshire, marine. & - & Nasare 2002 \\
\hline CCM-UDEC 114 & Tetraselmis sp. & Chile, coastal water at Coliumo Bay, Coliumo. & KF250348 & this study \\
\hline CCM-UDEC 109 & Tetraselmis sp. & Chile, tank at University of Concepción hatchery, Dichato. & KF 250349 & this study \\
\hline CCM-UDEC 134 & Tetraselmis sp. & Chile, coastal water at Caldera Bay, Caldera. & KF250350 & this study \\
\hline SAG $41.85^{*}$ & T. striata & UK. N-Wales, oyster rearing tanks at Conway, marine. & HE610129 & Marin 2012 \\
\hline SAG 17.86 & Scherffelia dubia & UK, Essex, pond in Epping Forest. & HE610128 & Marin 2012 \\
\hline
\end{tabular}

cells were centrifuged as above and the pellet resuspended in Walne medium to continue with the dehydration in a series of increasing concentrations of ethanol $(10 \%, 30 \%, 50 \%, 70 \%$, $90 \%, 95 \%, 98 \%$ and $100 \%$ ) for 15 min each. Afterward the cells were dried using the critical-point method with $\mathrm{CO}_{2}$, then covered with gold, and observed with a JEOL JSM 6380LV scanning electron microscope.

\section{MoleCUlar anALysis}

DNA EXTRACTION, AMPLIFICATION AND SEQUENCING

Total DNA was extracted according to the methodology described by Gómez \& González (2001). The ITS region was amplified with the primers AB28 (5'-ATATGCTTAAGTTCAGCGGGT-3') and TW81 (5'-GTTTCCGTAGGTGAACCTGC-3'), as described in Goff et al. (1994). Purification of the amplified fragments was done using the purification kit "Wizard SV and PCR Clean-Up System" (PROMEGA, USA). The purified fragments were cloned using the kit PGEM-T Easy Vector kit PROMEGA. Plasmids of the cloned sequences were sent to MACROGEN (Korea) for automated sequencing.

\section{Alignment AND PHYLOGENETIC ANALYSIS}

The consensus sequences of the ITS region (ITS-1, 5.8S, ITS2 ) obtained from the CLC Main Workbench program version 6.8.3 (CLC Bio, Denmark), were aligned using the Clustal W software (http://www.genome.jp/tools/clustalw/) and manually adjusted according to the secondary structure of both spacers (ITS-1 and ITS-2) (based on Coleman 2003, Mai $\&$ Coleman 1997). In this alignment, six further sequences were included, which were obtained from the GenBank (see Table I for details). The sister taxon of Tetraselmis, Scherffelia dubia was chosen as outgroup.

The resulting data of 9 strains with 488 aligned bases positions was used for the phylogenetic analyses. jModeltest 2 (Darriba et al. 2012) was used to determine the model of sequence evolution that fits best for the data set according to the Bayesian information criterion (BIC). Each spacer and the
5.8S gene were evaluated separately; in this case, a partitioning model was used. The best models for ITS-1, ITS-2 and 5.8S were $\mathrm{K} 80, \mathrm{~K} 80+\mathrm{G}$ and $\mathrm{JC}$, respectively. Bayesian phylogenetic analyses were conducted using MrBayes 3.1.2 (Ronquist \& Huelsenbeck 2003), with 30 million generations Markov Chain Monte Carlo (MCMC) sampled every 1000 generations.

ITS-2 SECONDARY STRUCTURE

The helices II and III from ITS-2 rDNA secondary structure of all the strains examined were obtained by using the program mfold (Zuker 2003, http://mfold.rna.albany.edu/?q=mfold/ RNA-Folding-Form), and the compensatory base pair changes (CBCs) have been manually identified.

\section{RESULTS}

Under light microscopy the cells of the three strains are similar in shape: slightly compressed, elliptical to ovate when viewed from the broad side. However, cells of the Coliumo strain when viewed from the narrow side are narrower at the base than the Dichato strain. On the other hand, cells from Caldera strain exhibited a slight torsion at the base when viewed from the same side. The sizes of the cells are different among the strains: Dichato strain is the smallest $(10-12.5 \mu \mathrm{m}$ length $x$ 5.8-8.0 $\mu \mathrm{m}$ wide; Fig. 1 A-C) while "Caldera" is the biggest (15-18.8 $\mu \mathrm{m}$ length, mainly $17.5 \mu \mathrm{m}$ length $\mathrm{x} 8.5-$ $12.5 \mu \mathrm{m}$ wide; Fig. $1 \mathrm{G}-\mathrm{I})$. The strain from Coliumo exhibits intermediate sizes (12.5 - $15 \mu \mathrm{m}$ length; mainly $15 \mu \mathrm{m}$ length x 6.5 to $9.5 \mu \mathrm{m}$ wide; Fig.1 D-F). Another feature clearly visible using light microscopy was the pyrenoid position within the chloroplast: mostly basal in the Dichato strain and sub-basal to sub-central in the Coliumo and Caldera strains (Fig. 1). The three strains have one eyespot with variable position within the chloroplast. Asexual reproduction was observed in the three strains; thus two daughter cells within the mother theca were seen in the strains from Dichato and Coliumo (Fig. 1 A, F), while the strain from "Caldera" 


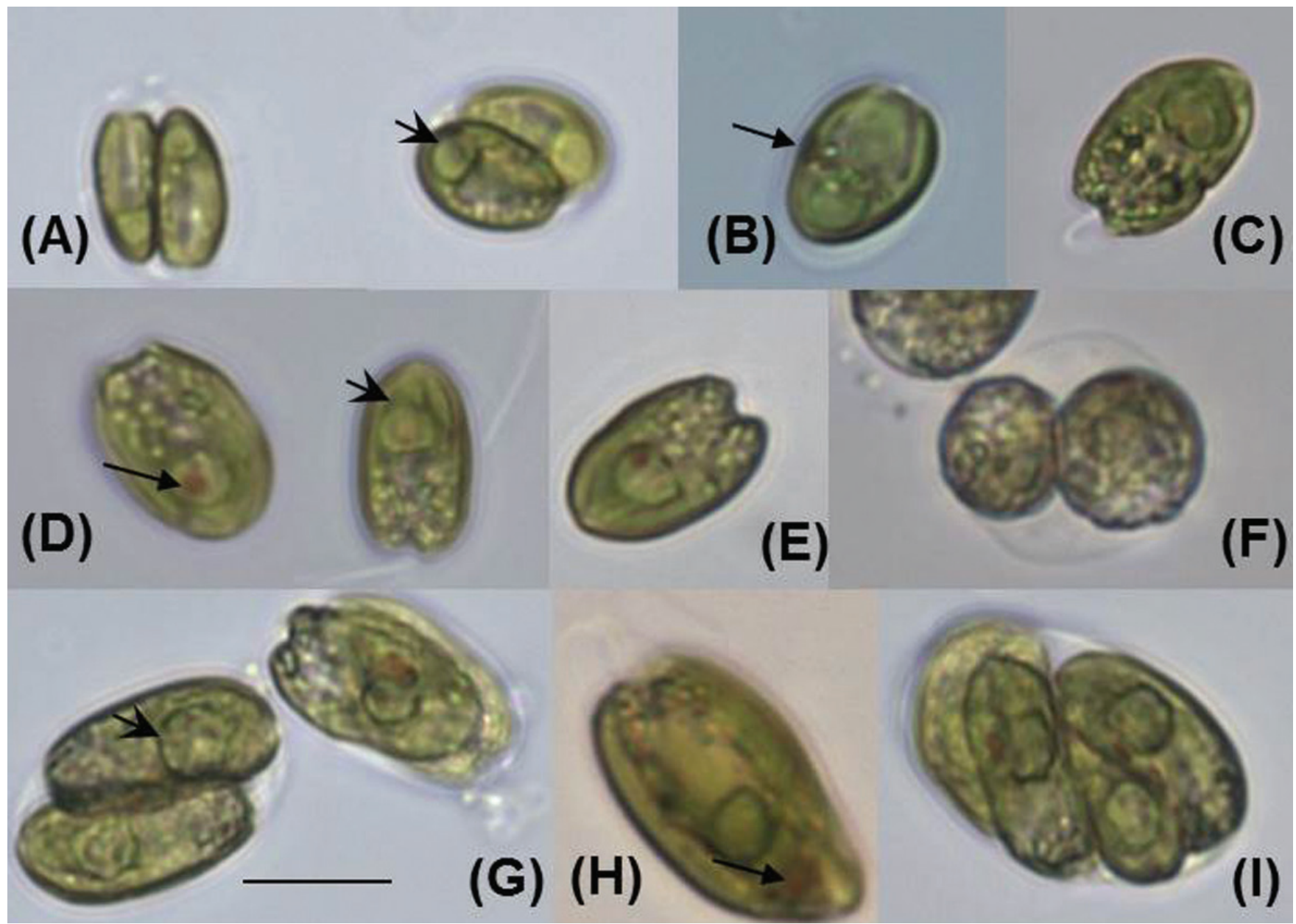

FIgURE 1. Light micrographs of the Chilean Tetraselmis strains. Dichato strain (A-C), Coliumo strain (D-F) and Caldera strain (G-I). Note the position of the pyrenoid (arrow head) and stigma (arrow). Scale bar $=10 \mu \mathrm{m}$.

Figura 1. Fotomicrografias fotónicas de las cepas chilenas de Tetraselmis. Cepa de Dichato (A-C), cepa de Coliumo (D-F) y cepa de Caldera (G-I). Note la posición del pirenoide (punta de flecha) y estigma (flecha). Escala $=10 \mu \mathrm{m}$.

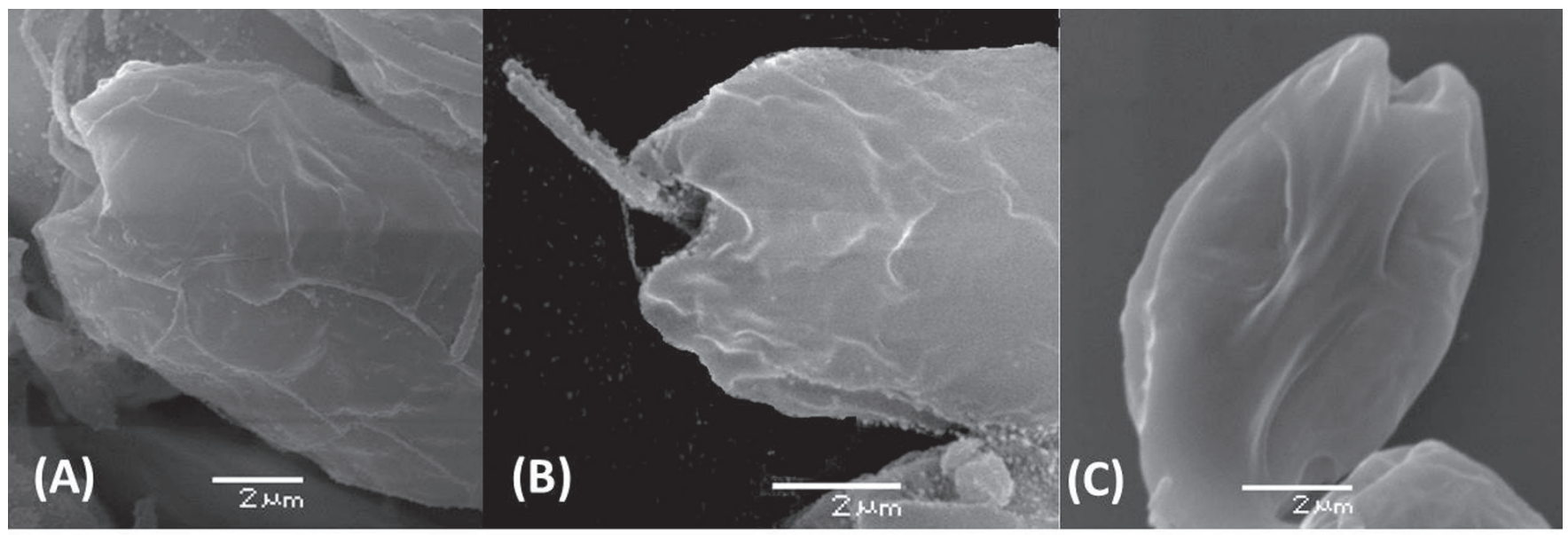

FIGURE 2. Scanning electron micrographs of the Chilean Tetraselmis strains. Cells of the Dichato (A), Coliumo (B) and Caldera (C) strains, denoting the presence of only two apical lobes, in each one.

Figura 2. Fotomicrografías electrónicas de barrido de las cepas chilenas de Tetraselmis. Células de las cepas de Dichato (A), Coliumo (B) y Caldera (C), mostrando la presencia de dos lóbulos apicales en cada una. 

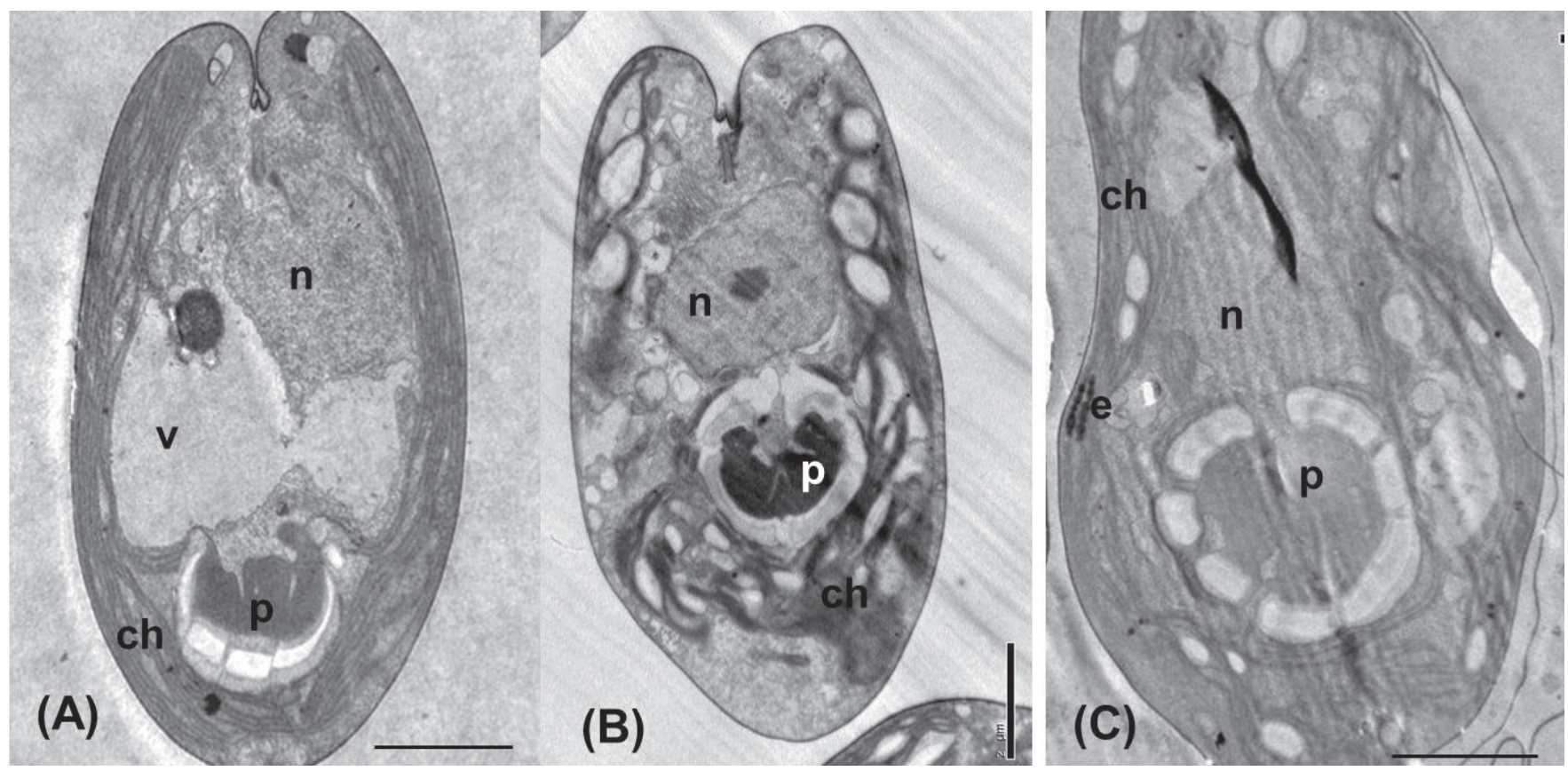

Figure 3. Transmission electron micrographs of the Chilean Tetraselmis strains. Longitudinal sections of cells from Dichato (A), Coliumo (B) and Caldera (C) showing the position of the pyrenoid (basal in A and sub-basal in B and C) and the lobed or non- lobed chloroplast at the cell posterior $(\mathrm{B}$ versus $\mathrm{A}) . \mathrm{n}=$ nucleus, $\mathrm{p}=$ pyrenoid, $\mathrm{ch}=$ chloroplast, $\mathrm{e}=$ eyespot, $\mathrm{v}=$ vacuole. Scale bars $=2 \mu \mathrm{m}$.

Figura 3. Fotomicrografías electrónicas de transmisión de las cepas chilenas de Tetraselmis. Células en sección longitudinal de las cepas de Dichato (A), Coliumo (B) y Caldera (C) mostrando la posición del pirenoide (basal en A y subbasal en B y C) y la presencia o no de lobulación del cloroplasto en la parte posterior de la célula $(B$ versus $A)$. $n=$ núcleo, $p=$ pirenoide, $c h=$ cloroplasto, e e estigma, $v=$ vacuola. Escalas $=2 \mu \mathrm{m}$.

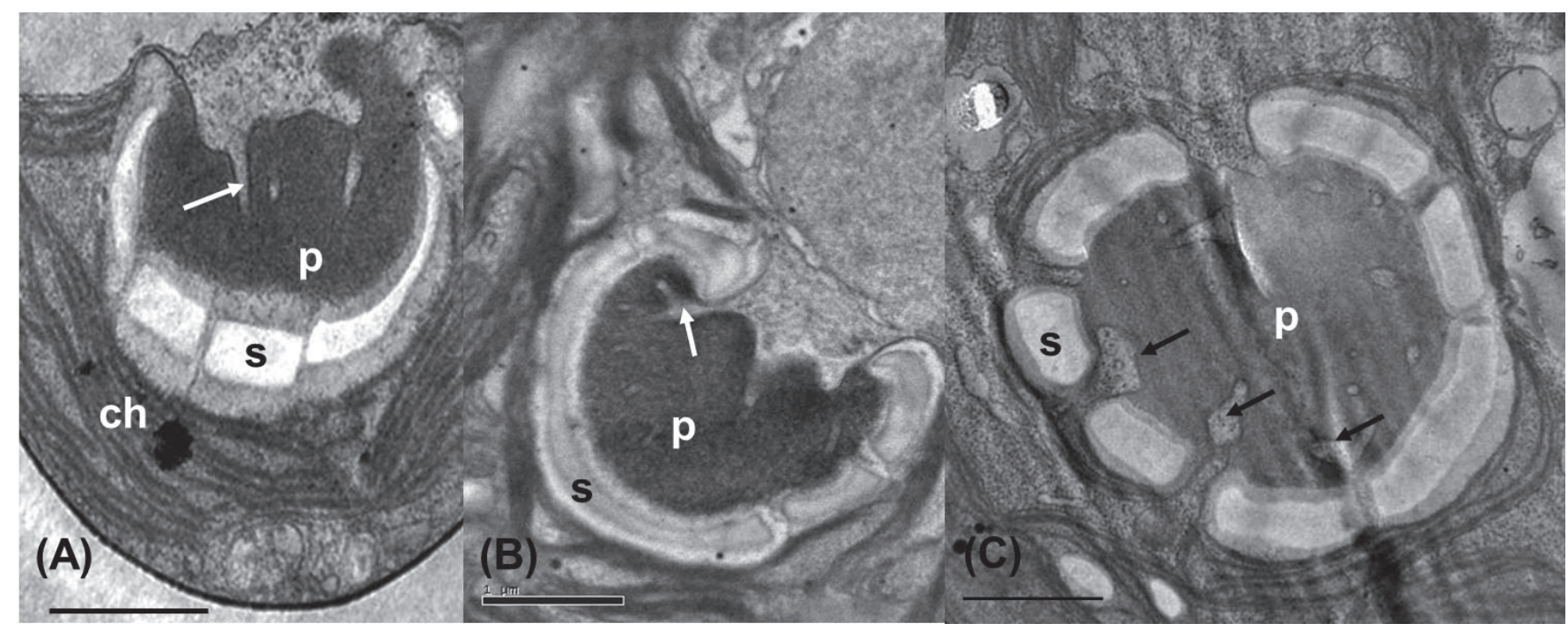

FiguRE 4. Transmission electron micrographs of the Chilean Tetraselmis strains. Close up of cells showing the ultrastructure of the pyrenoids (p) in (A) Dichato, (B) Coliumo and (C) Caldera strains. Note the characteristic "horseshoe" shape in A and B and a cavity from which cytoplasmic canaliculi extend and end blindly (white arrows). In C the pyrenoid is rounded and its matrix is transversed by various cytoplasmic channels (black arrows). $\mathrm{ch}=$ chloroplast, $\mathrm{s}=$ starch. Scale bars $=1 \mu \mathrm{m}$.

FiguRA 4. Fotomicrografías electrónicas de transmisión de las cepas chilenas de Tetraselmis. "Close-up" celular mostrando la ultraestructura del pirenoide (p) en las cepas de Dichato (A), Coliumo (B) y Caldera (C). Note la forma característica tipo "herradura" en A y B y la cavidad del pirenoide con canalículos citoplasmáticos que terminan ciegos (flechas blancas). En C, el pirenoide es redondo y su matriz se encuentra atravesada por varios canales citoplasmáticos (flechas negras). $\mathrm{ch}=$ cloroplasto, $\mathrm{s}=$ almidón. Escalas $=1 \mu \mathrm{m}$. 


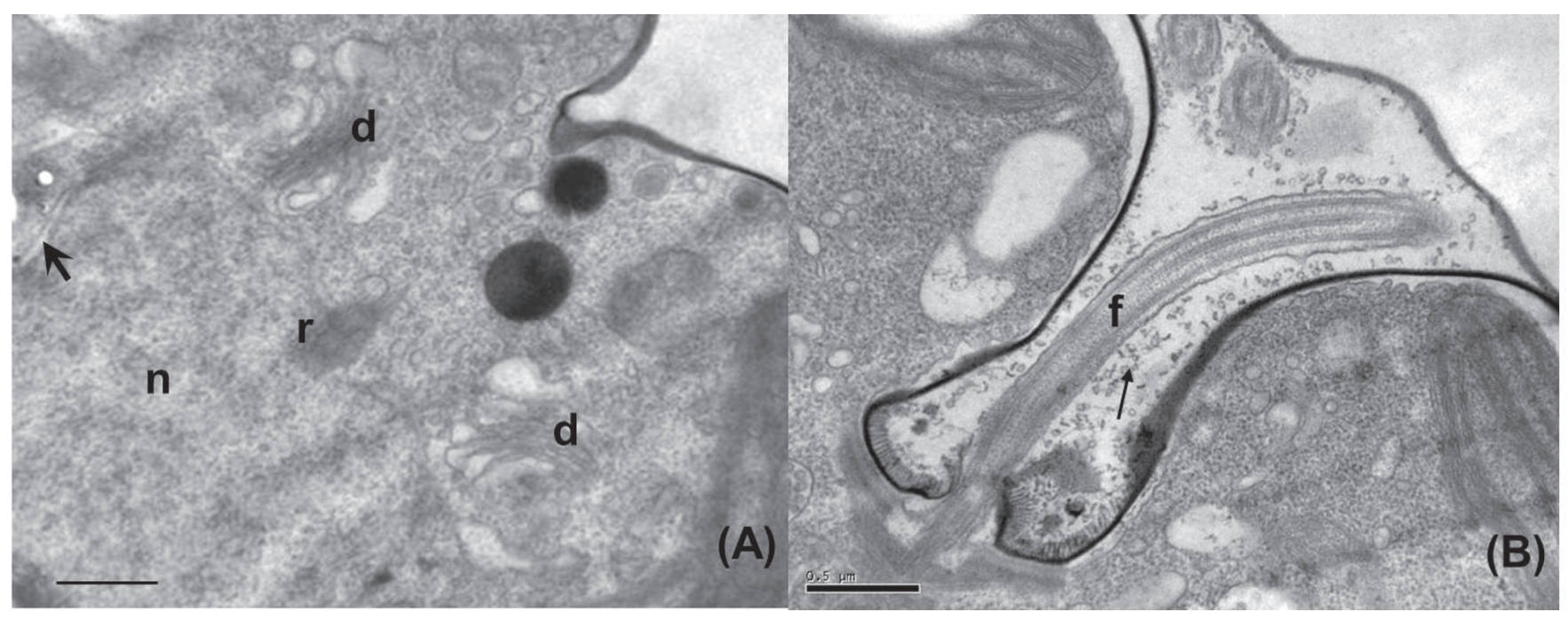

Figure 5. Transmission electron micrographs of the Coliumo strain of Tetraselmis. Longitudinal section of the apical portion of the cell. In A note the two dictyosomes (d), part of the rhizoplast (r) and the nucleus (n). In B the apical depression, one emerging flagellum (f) and numerous scales (arrow). Arrow head $=$ nuclear membrane. Scale bars $=0.5 \mu \mathrm{m}$.

Figura 5. Fotomicrografías electrónicas de transmisión de la cepa Coliumo de Tetraselmis. Sección longitudinal de la porción apical de la célula. En A note la presencia de dos dictiosomas (d), parte del rizoplasto (r) y el núcleo (n). En B se observa la depresión apical, uno de los flagelos (f) y la presencia de numerosas escamas (flechas). Punta de flecha $=$ membrana nuclear. Escalas $=0.5 \mu \mathrm{m}$.

exhibited 2 or 4 daughter cells within the mother theca (Fig. 1 $\mathrm{G}, \mathrm{I})$. The cells of the three strains exhibited a rather shallow two-lobed apical furrow that was clearly seen in SEM observations (Fig. 2 A-C).

Under TEM the cells of the three strains are covered with a smooth theca and have one cup shaped chloroplast (Fig. 3). The chloroplast of the Coliumo strain is lobed at the posterior part of the cell while the chloroplast of the Dichato strain is not lobed (Fig. 3 A, B). The pyrenoid in the Coliumo and Dichato strains of around $2.2 \mu \mathrm{m}$ in diameter is surrounded by starch grains which are concave-convex in shape (Fig. $4 \mathrm{~A}$, B). The pyrenoid cavity is usually open towards the nucleus and has cytoplasmic channels which end within the matrix as shown in Figure $4 \mathrm{~A}$ and B. Due to the presence of this cavity, the pyrenoid has generally a horseshoe-shape when viewed in longitudinal section. The nucleus is located at the anterior middle of the cell (Fig. 3 A, B) and two dictyosomes are present at each side of the flagellar base (Fig. 5 A).

In spite of similarities in chloroplast shape and pyrenoid location as described above, the strain from Caldera exhibited a quite different pyrenoid shape and ultrastructure. The pyrenoid is spherical, $3.0-3.5 \mu \mathrm{m}$ in diameter. The pyrenoid cavity is open to the nucleus and its matrix is invaded by several cytoplasmic channels that transverse it in various directions (Figs. $3 \mathrm{C}$ and $4 \mathrm{C}$ ). The morphological and ultrastructural characters of the examined strains of Tetraselmis are summarized in Table II.

The phylogenetic analysis of the nuclear ribosomal internal transcribed spacers ITS-1 and ITS-2 sequences presented in Figure 6 revealed that the Coliumo and Dichato strains group together forming the clade III (Fig. 6) containing the species of the subgenus Parviselmis: T. chui (CCAP 8/6, CCAP 66/21B) and T. suecica (WDCM NCC62). The ITS-1 and ITS-2 sequences of the Coliumo strain differ only in one base compared to those of the Dichato strain. However, when the secondary structure of ITS-2 is observed, specifically the helix III, no differences in sequence are observed neither between both strains nor with the strains of $T$. chui and T. suecica included in this study. We get the same result by analyzing the helix II of the same spacer; except for one nucleotide difference in the Coliumo strain (Figs. 7 and 8).

The Caldera strain, on the other hand, appears alone, forming its own clade in the tree (see clade II in Fig. 6). ITS-1 and ITS-2 sequences of this strain differ in 18 and 45 nucleotides compare to Coliumo and Dichato strains, and to T. chui and T. suecica sequences, respectively. Most of the sequence differences were located in helix III and helix II of the ITS-2.

Interestingly, the strain of $T$. striata included in this study, which also belong to the subgenus Parviselmis form its own clade (clade I in Fig. 6) separated from other clades, which contain the Chilean strains.

\section{DISCUSSION}

The strains of Tetraselmis from Dichato (CCM-UDEC 109) and Coliumo (CCM-UDEC 114) shared the typical pyrenoid ultrastructure defined for the subgenus Parviselmis by Hori et al. (1983), which is the pyrenoid cavity open towards the nucleus and the presence of cytoplasmic channels without 


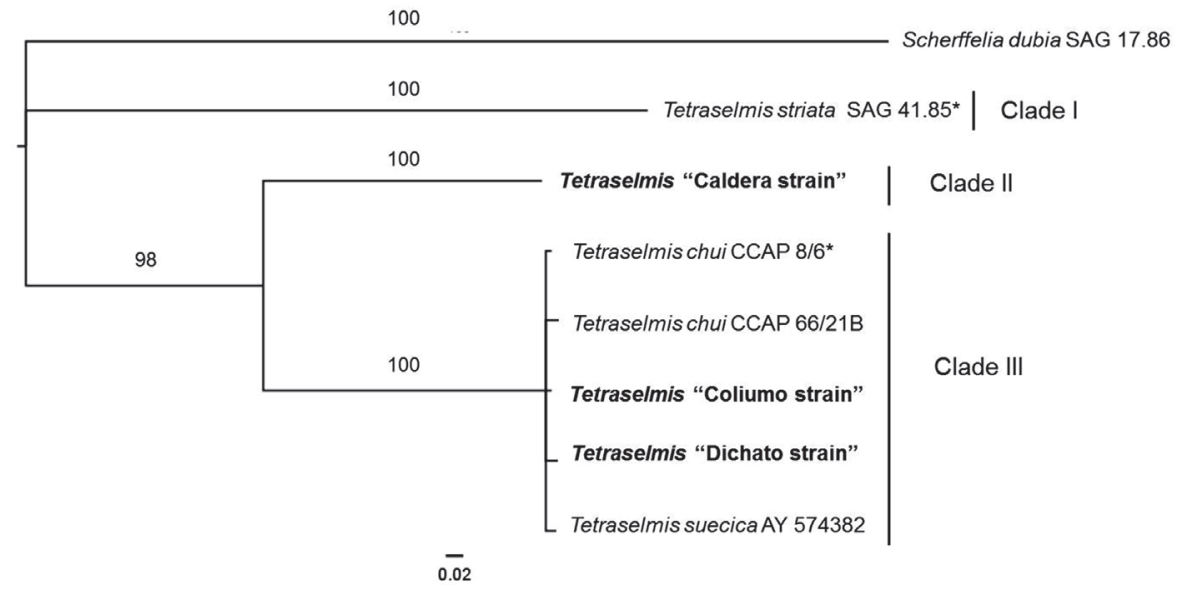

FIGURE 6. Molecular phylogeny of the Tetraselmis strains included in this study. Bayesian phylogenetic tree (50\% majority rule consensus), as inferred from ITS-1, ITS-2 and 5.8S gene of nuclear rDNA sequences. Numbers above branches indicate the Bayesian values (posterior probability). Scale bar $=$ substitutions per site. ${ }^{*}=$ authentic strains.

Figura 6. Filogenia molecular de las cepas de Tetraselmis en estudio. Arbol filogenético de inferencia Bayesiana (consenso, regla de la mayoría 50\% ) basado en las secuencias de los espaciadores ITS-1, ITS-2 y gen 5.8S del DNA ribosomal nuclear. Los números sobre las ramas indican los valores Bayesianos (probabilidad posterior). Escala $=$ sustituciones por sitio. *= cepas auténticas.

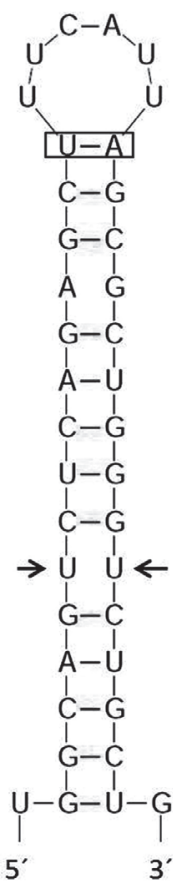

(A)

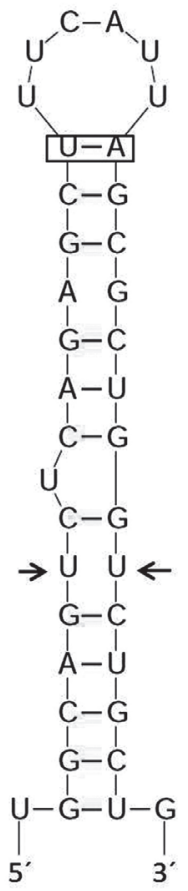

(B)

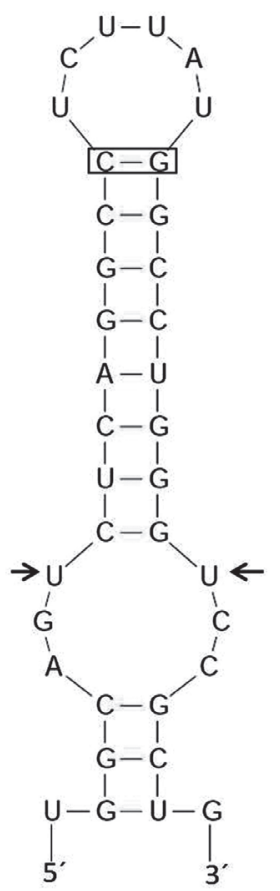

(C)

FIGURE 7. Predicted secondary structures of nuclear ITS-2 helix II (clockwise from 5' termini to 3 'termini) from Tetraselmis chiu, T. suecica and the Chilean strains under study. (A) Dichato strain, T. chui CCAP 8/6 and CCAP 66/21B and T. suecica AY574382.1, (B) Coliumo strain and (C) Caldera strain. The compensatory base changes are highlighted in boxes. The arrows mark the putative RNA processing sites.

FIgURA 7. Estructuras secundarias predichas de la hélice II del espaciador nuclear ITS-2 (del terminal 5'al 3') de Tetraselmis chui, T. suecica y las cepas chilenas de Tetraselmis en estudio. (A) Cepa Dichato, T. chui CCAP 8/6 y CCAP 66/21B y T. suecica AY574382.1, (B) cepa Coliumo y $(\mathrm{C})$ cepa Caldera. Los cambios compensatorios de bases están marcados en rectángulos. Las flechas indican los supuestos sitios de procesamiento del RNA. 
Gayana Bot. 72(1), 2015

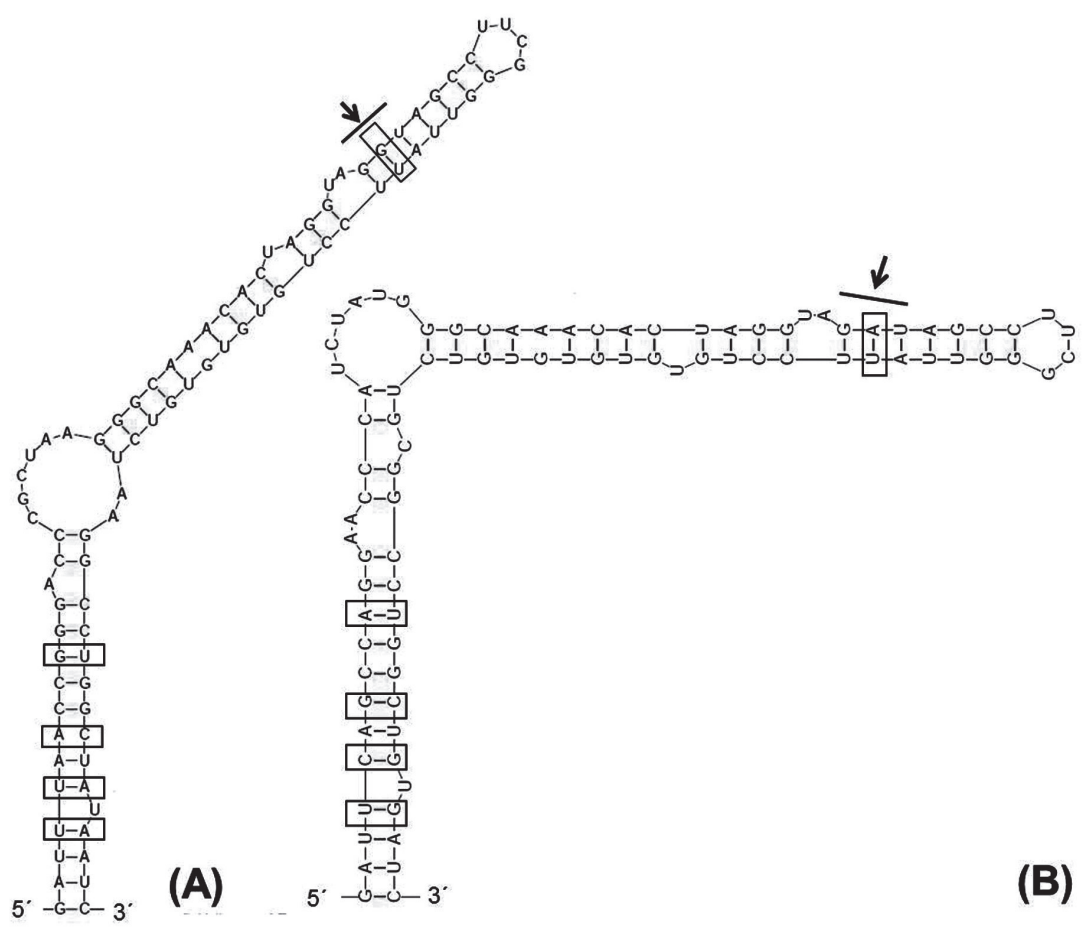

FIGURE 8. Predicted secondary structures of the nuclear ITS-2 helix III (clockwise from 5 ' termini to 3 'termini) from Tetraselmis chui, T. suecica and the Chilean strains under study. (A) Dichato strain, Coliumo strain, T. chui CCAP 8/6 and CCAP 66/21B and T. suecica AY574382.1 and (B) Caldera strain. The compensatory base changes are highlighted in boxes. The arrows marked the putative RNA processing sites.

Figura 8. Estructuras secundarias predichas de la hélice III del espaciador nuclear ITS-2 (del terminal 5'al 3') de Tetraselmis chui, T. suecica y las cepas chilenas de Tetraselmis en estudio. (A) Cepa Dichato, cepa Coliumo T. chui CCAP 8/6 y CCAP 66/21B y T. suecica AY574382.1 y (B) cepa Caldera. Los cambios compensatorios de bases están marcados en rectángulos. Las flechas indican los supuestos sitios de procesamiento del RNA.

dissection of the pyrenoid matrix. Moreover, the cells of both strains have two dictyosomes present in the vicinity of the flagellar base which is a feature of most of the species assigned to the subgenus Parviselmis according to Hori et al. (1986).

Based on the morphological and molecular data obtained from this study both strains could belong either to $T$. suecica (Kylin) Butcher or to T. chui Butcher. The described differences between both species according to Butcher (1959) and Hori et al. (1986) are the slightly difference in cell size and shape, as well as, in chloroplast shape and the locations of the pyrenoid and eyespot within the cell. However, there is incongruence in the descriptions provided by Butcher (1959) and Hori et al. (1986) concerning the position of the pyrenoid and the shape of the chloroplast at the posterior of the cell in these two species. Thus, Hori et al. (1986) described $T$. suecica as having an unlobed chloroplast at the posterior end, and that the location of the pyrenoid is basal. This is in contrast to T. chui, which has a finely lobed chloroplast at the posterior part of the cell and its pyrenoid is located sub-basal to sub-centrally. Butcher (1959), however, stated that the pyrenoid position in T. chui (in contrast to T. suecica) is basal and that the chloroplast is not lobed at the posterior end of the cell. The morphological variability within Tetraselmis needs to be proven in comprehensive comparative study using the authentic strains of the species.

The ITS-1 and ITS-2 sequence data show the close phylogenetic relationship of the Coliumo and the Dichato strains to sequences of T. chui and T. suecica. Moreover, a comparison of the secondary structure of the ITS-2, showed no compensatory base changes in the conserved region of the ITS-2 (specifically in helix II and III) of the strains belonging to clade III. The CBCs in the secondary structure of the ITS2 have often been taken into account when distinguishing between closely related species (Luo et al. 2006, Krienitz et al. 2010, Bock et al. 2010, 2011, Pröschold et al. 2011). Studies have shown that one CBC in the conserved region of the helix II or III of the ITS-2 is, in most cases, associated with an inability for sexual reproduction (Coleman \& Mai 1997, Coleman 2007, 2009). Therefore, based on these results, we can conclude that the strains from Coliumo and Dichato (CCM-UDEC 114, CCM-UDEC 109), as well as the other strains (WDCM NCC 62, CCAP 8/6, CCAP 66/21B) 
TABLE II. Morphological and ultrastructural characters of the examined strains of Tetraselmis.

TABLA II. Caracteres morfológicos y ultraestructurales de las cepas de Tetraselmis examinadas.

\begin{tabular}{|c|c|c|c|c|c|c|}
\hline StRAINS & $\begin{array}{l}\text { CeLl SIZE } \\
(\mu \mathrm{m})\end{array}$ & $\begin{array}{l}\text { CELL } \\
\text { SHAPE }\end{array}$ & $\begin{array}{l}\mathrm{N}^{\circ} \text { LOBES IN } \\
\text { CELL APEX }\end{array}$ & $\begin{array}{c}\text { Chloroplast } \\
\text { SHAPE AT } \\
\text { CELL BASE } \\
\end{array}$ & $\begin{array}{l}\text { POSITION OF } \\
\text { THE PYRENOID }\end{array}$ & $\begin{array}{l}\text { ULTRASTRUCTURE } \\
\text { OF PYRENOID }\end{array}$ \\
\hline $\begin{array}{l}\text { Coliumo } \\
\text { (CCM- } \\
\text { UDEC 114) }\end{array}$ & $\begin{array}{l}12.5-15 \\
\text { length } x \\
6.5-9.5 \text { wide }\end{array}$ & $\begin{array}{l}\text { In lateral view : } \\
\text { narrower at the } \\
\text { cell base. }\end{array}$ & 2 & Lobed & Sub-basal to sub-central & $\begin{array}{l}\text { Horseshoe-shape. } \\
\text { Cytoplasmic channels end } \\
\text { within the pyrenoid matrix. }\end{array}$ \\
\hline $\begin{array}{l}\text { Dichato } \\
\text { (CCM- } \\
\text { UDEC 109) }\end{array}$ & $\begin{array}{l}10-12.5 \\
\text { length } \mathrm{x} \\
5.8-8.0 \text { wide }\end{array}$ & $\begin{array}{l}\text { In lateral view: } \\
\text { rounded at the } \\
\text { cell base }\end{array}$ & 2 & Not-lobed & Basal & $\begin{array}{l}\text { Horseshoe-shape. } \\
\text { Cytoplasmic channels end } \\
\text { within the pyrenoid matrix. }\end{array}$ \\
\hline $\begin{array}{l}\text { Caldera } \\
\text { (CCM- } \\
\text { UDEC 134) }\end{array}$ & $\begin{array}{l}15-18.8 \\
\text { length } x \\
8.5-12.5 \text { wide }\end{array}$ & $\begin{array}{l}\text { In lateral view: } \\
\text { narrower and curved } \\
\text { at the cell base }\end{array}$ & 2 & Lobed & Sub-basal to sub-central & $\begin{array}{l}\text { Spherical in shape. } \\
\text { Cytoplasmic channels } \\
\text { transverse the pyrenoid } \\
\text { matrix }\end{array}$ \\
\hline
\end{tabular}

included in this study, belong to the same species. At present it cannot be decided which species name should be chosen ( $T$. suecica or T. chui). However, the strain CCAP 8/6 of T. chui is the authentic strain of this species, whereas the authentic strain of the other species is not available in public culture collection. If an epitype of T. suecica will be designated, this species name has priority according to the International Code of Nomenclature for Algae, Fungi and Plants. To solve this problem, it will be necessary to include more strains in comparative studies using an integrative approach as indicated by Pröschold \& Leliaert (2007).

Based on pyrenoid ultrastructure (pyrenoid cavity opening towards the nucleus and cytoplasmic channels traversing its matrix in different directions), the strain of Tetraselmis from Caldera (CCM UDEC 134) belongs to the subgenus Tetrathele (Hori et al. 1983). Despite that many strains of $T$. tetrathele are available in public culture collections, no morphological and molecular study of this species has been published so far. Only Butcher (1959) compared the morphology of this species with the others of this genus.

The comparison of the morphology of the Caldera strain shows similarities to those published by Butcher (1959) for T. tetrathele: cell size, shape (in lateral view: the posterior part of the cell acute, slightly twisted and curved) and the position of the pyrenoid (sub-central to sub-basal). Butcher also mentioned the spherical shape of the pyrenoid, which was also observed in cells of the Caldera strain under TEM. Caldera strain cells differ from the Butcher's description in the presence of only two apical lobes (instead of four) and the absence of a lateral deep longitudinal furrow. Until now there is no ITS- 1 and ITS-2 rDNA sequences available in the GenBank of strains belonging to this species. Therefore, it is difficult to make a conclusion about taxonomic identity of the Caldera strain.

Summarizing our results, the Coliumo and Dichato strains correspond to the same species, which is identical to the authentic strain of T. chui Butcher. The Caldera strain showed some morphological differences to the original description of T. tetrathele (as emended in Butcher 1959), and can therefore represent an undescribed species within the subgenus Tetrathele. However, the taxonomic revision of this genus is necessary by including of more strains.

In addition, the subdivision into subgenera as introduced by Hori et al. (1986) is probably artificial and needs further studies. According to Hori T. striata belongs to the same subgenus Parviselmis like the strains of T. chui. However, both species form separate clades in our phylogeny (Fig. 6).

Furthermore, the authentic strain of T. striata (which belongs to the subgenus Parviselmis) is phylogenetically more distant to clade III than the Caldera strain, which fits within the subgenus Tetrathele according to the pyrenoid ultrastructure. These results highlight the need for testing the validity of the pyrenoid ultrastructure as the predicting attribute used to recognize subgenera within the genus Tetraselmis. This issue has not been taken into account in any molecular phylogenetic studies previously published on this genus (Nasare 2002, Lee \& Hur 2009, Arora et al. 2013).

\section{ACKNOWLEDGMENTS}

We thank Dr. Annette W. Coleman for her help in the sequences alignment adjustment and Dr.Thomas Pröschold for helping us with the ITS-2 secondary structure. This work was funded by "Fondo de Fomento al Desarrollo Científico y Tecnológico" (FONDEF) Projects \# D07I-1063 and \# D07I-1017.

\section{REFERENCES}

Andersen, R.A. 2005. Algal Culturing Techniques. Elsevier Academic Press. pp: 507, 519.

Arora, M., A.C. Anil, F. Leliaert, J. Delany \& E. Mesbahi. 2013. Tetraselmis indica (Chlorodendrophyceae, Chlorophyta), a new species isolated from salt pans in Goa, India. European 
Journal of Phycology 48: 61-78.

Becker, D., B. Becker, P. SAtir \& M. Melkonian. 1990. Isolation, purification, and characterization of flagellar scales from the green flagellate Tetraselmis striata (Prasinophyceae). Protoplasma 156: 103-112.

Becker, B., M. Marin \& M. Melkonian. 1994. Structure, composition, and biogenesis of prasinophyte cell coverings. Protoplasma 181: 233-244.

Bock, A., L. Kriesnitz \& T. Pröschold. 2011. Taxonomic reassessment of the genus Chlorella (Trebouxiophyceae) using molecular signatures (barcodes), including description of seven new species. Fottea 11: 293-312.

Bock, A., T. Pröschold \& L. Kriesnitz. 2010. Two new Dictyosphaerium-morphotype lineages of the Chlorellaceae (Trebouxiophyceae): Heynigia gen. nov. and Hindakia gen. nov. European Journal of Phycology 45: 267-277.

BRown, M.R. 2002. Nutritional value of microalgae for aquaculture. In: L.E. Cruz-Suárez, D. Ricque-Marie, M. Tapia-Salazar, M.G. Gaxiola-Cortés \& N. Simoes (eds.), Avances en Nutrición Acuícola VI. Memorias del VI Simposium Internacional de Nutrición Acuícola. 3 al 6 de septiembre de 2002. Cancún, Quintana Roo, México.

ButcheR, R.W. 1959. An introductory account of the smaller algae of the British Coastal Waters. Part 1: Introduction and Chlorophyceae. Fishery investigations. Ministry of Agriculture, Fisheries and Food. Series IV. Her Majesty's Stationery Office, London.

Catalán, A. 1996. Aislación y cultivo de microalgas. Tesis para optar al Grado de Licenciado en Biología Marina. Instituto de Oceanología. Universidad de Valparaíso, Valparaíso, Chile, $238 \mathrm{pp}$.

Coleman, A.W. 2003. ITS2 is a double-edged tool for eukaryote evolutionary comparisons. Trends in Genetics 19: 370-375.

Coleman, A.W. 2007. Pan-eukaryote ITS2 homologies revealed by RNA secondary structure. Nucleic Acids Research 35: 33223329.

Coleman, A.W. 2009. Is there a molecular key to the level of "biological species" in eukaryotes? A DNA guide. Molecular Phylogenetics and Evolution 50: 197-203.

Coleman, A.W. \& J.C. MaI. 1997. Ribosomal DNA ITS-1 and ITS-2 sequence comparisons as tool for predicting genetic relatedness. Journal of Molecular Evolution 45: 168-177.

Darriba, D., G.L. Taboada, R. Doallo \& D. Posada. 2012. jModelTest 2: more models, new heuristics and parallel computing. Nature Methods 9: 772.

De la Pena, M.R. \& C.T. Villegas. 2005. Cell growth, effect of filtrate and nutritive value of the tropical Prasinophyte Tetraselmis tetrathele (Butcher) at different phases of culture. Aquaculture Research 36: 1500-1508.

DsouzA, F.M.L. \& G.J. KelLy. 2000. Effects of a diet of a nitrogenlimited alga (Tetraselmis suecica) on growth, survival and biochemical composition of tiger prawn (Penaeus semisulcatus) larvae. Aquaculture 181: 311-329.

Goff, L.J., D.A. Moon \& A.W. Coleman. 1994. Molecular delineation of species and species relationships in the red algal agarophytes Gracilariopsis and Gracilaria (Gracilariales). Journal of Phycology 30: 521-537.

Gómez, P.I. \& M.A. GonZÁLEZ. 2001. Genetic polymorphism in eight Chilean strains of the carotenogenic microalga Dunaliella salina Teodoresco (Chlorophyta). Biological Research 34: 23-30.
Graham, L.E. \& L.W. Wilcox. 2000. Algae. Prentice-Hall, Inc. Nj, Usa. $640 \mathrm{pp}$.

Grierson, S., V. Strezov, S. Bray, R. Mummacari, L.T. Danh \& N. Fosters. 2012. Assessment of bio-oil extraction from Tetraselmis chui microalgae comparing supercritical $\mathrm{CO}_{2}$, solvent extraction, and thermal processing. Energy and Fuels 26: 248-255.

Hori, T., R.E. Norris \& M. ChiHara. 1982. Studies on the ultrastructure and taxonomy of the genus Tetraselmis (Prasinophyceae). I. Subgenus Tetraselmis. Botanical Magazine (Tokyo) 95: 49-61.

Hori, T., R.E. Norris \& M. Chihara. 1983. Studies on the ultrastructure and taxonomy of the genus Tetraselmis (Prasinophyceae) II. Subgenus Prasinocladia. BotanicalMagazine (Tokyo) 96: 385-392.

Hori, T., R.E. Norris \& M. ChiHara. 1986. Studies on the ultrastructure and taxonomy of the genus Tetraselmis (Prasinophyceae). III. Subgenus Parviselmis. Botanical Magazine (Tokyo) 99: 123-135.

Hoshaw, R.W. \& J.R. Rosowski. 1973. Methods for microscopic algae. In: J. Stein (ed.), Handbook of Phycological Methods. Culture methods and growth measurements, London, Cambridge University Press, pp: 54-66.

Joubert, Y., G. Rousse, J.M. Robert \& J. Fleurence. 2002. Ribosomal DNA ITS region amplification as a tool for species identification of some micro algae. (Unpublished) (http://www.ncbi.nlm.nih.gov/nuccore/AY574382.1).

Krienitz, L., C. Bock, W. Luo \& T. Pröschold. 2010. Polyphyletic origin of the Dictyosphaerium-morphotype within Chlorellaceae (Trebouxiophyceae). Journal of Phycology 46: 559-563.

LaZA-Martinez, A. 2012. Urgorri complanatus gen. et sp. nov. (Cryptophyceae), a red-tide-forming species in brackish waters. Journal of Phycology 48: 423-435.

LeE, H.J. \& S.B. Hur. 2009. Genetic relationships among multiple strains of the genus Tetraselmis based on partial 18S rDNA sequences. Algae 24: 205-212.

Luo, W., S. Pflugmacher, T. Pröschold, N. Walz \& L. Krienitz. 2006. Genotype versus phenotype variability in Chlorella and Micractinium (Chlorophyta, Trebouxiophyceae). Protist 157: $315-333$

MaI, J.C. \& A.W. Coleman. 1997. The internal transcribed spacer 2 exhibits a common secondary structure in green algae and flowering plants. Journal of Molecular Evolution 44: 258-271.

Marin, B. 2012. Nested in the Chlorellales or independent class? Phylogeny and classification of the Pedinophyceae (Viridiplantae) revealed by molecular phylogenetic analyses of complete nuclear and plastid-encoded rRNA operons. Protist 163: 778-805.

Marin, B., C. Matzke \& M. Melkonian. 1993. Flagellar hairs of Tetraselmis (Prasinophyceae): ultrastructural types and intrageneric variation. Phycologia 32: 213-222.

Melkonian, M. 1982. Effect of divalent cations on flagellar scales in the green flagellate Tetraselmis cordiformis. Protoplasma 111: 221-233.

MeseCK, L.S.T., H.A. JenNifer \& H.G. WiKfors. 2005. Photoperiod and light intensity effects on growth and utilization of nutrients by the aquaculture feed microalga, Tetraselmis chuii (PLY429). Aquaculture 246: 393-404.

Moestrup, O. \& J. Throndsen. 1988. Light and electron microscopical studies on Pseudoscourfieldia marina, a primitive scaly 
green flagellate (Prasinophyceae) with posterior flagella. Canadian Journal of Botany 66: 1415-1434.

Montero, M.F., M. AristizÁbal \& G.G. Reina. 2010. Isolation of high-lipid content strains of the marine microalga Tetraselmis suecica for biodiesel production by flow cytometry and single cell sorting. Journal of Applied Phycology 23: 10531057.

Müller, T., N. Philippi, T. Dandekar, J. Schultz \& M. Wolf. 2007. Distinguishing species. RNA 13: 1469-1472.

NASARE, K.S. 2002. Morphological characterization and DNA fingerprinting of a Prasinophyte flagellate isolated from Kerla Coast. PhD Dissertation in Botany, University of Pune, India. 127 pp.

Pröschold, T. \& F. Leliaert. 2007. Systematics of the green algae: conflict of classic and modern approaches. In: J. Brodie \& J. Lewis (eds.), Unravelling the algae. The past, presente, and future of algal systematics. The Systematics Association Special Volume, Ser. 75, CRC Press, Taylor \& Francis Group, Boca Raton, FL, USA. pp:123-153.

Pröschold, T., T. Darienko, P.C. Silva, W. Reisser \& L. Krienitz. 2011. The systematics of Zoochlorella revisited employing an integrative approach. Environmental Microbiology 13: 350-364.

REYNOLDS, E.S. 1963. The use of lead citrate at high $\mathrm{pH}$ as an electron-opaque stain in electron microscopy. Journal of Cell Biology 17: 208-212.

Ronquist, F. \& J.P. Huelsenbeck. 2003. MrBayes 3: Bayesian phylogenetic inference under mixed models. Bioinformatics 19: $1572-1574$.

ZUKER, M. 2003. Mfold web server for nucleic acid folding and hybridization prediction. Nucleic Acids Research 31: 34063415.

Recibido: 12.03 .14

Aceptado: 16.10 .14 